\title{
Production of Synbiotic-Drinkable Yoghurt Fortified with Different Probiotic Strains and Oat \\ M.B. El-Alfy ${ }^{1}$; Shenana ${ }^{1}$ M.E.; Essawy ${ }^{2}$ E.A.; Abd El-Halim² S.E.; and Ismail ${ }^{1}$ E.A. \\ ${ }^{1}$ Dairy Sci., Dept., Fac., of Agric., , Moshtohor, Benha University, Egypt \\ ${ }^{2}$ Dairy Res., Dept., Food Tech., Res., Institute, Agric., Res., Center, Ministry of Agriculture, Egypt \\ Corresponding author: mbeALFY@ fagr.bu.edu.eg
}

\begin{abstract}
Synbiotic-drinkable yoghurt was produced by using some new probiotic bacteria and enriched with $1 \%$ oat. The resultant synbiotic-drinkable yoghurts were stored at $5^{\circ} \mathrm{C}$ and analyzed for physico-chemical, rheological, microbiological and sensory properties when fresh and after 7, 14 and 21 days. The obtained results cleared that the acid development of probiotic bacteria revealed that control sample $\left(\mathrm{C}_{1}\right)$ without probiotic strains or oat and yoghurt with Bifidobacterium breve (B) recorded the highest $\mathrm{pH}$ values, while yoghurt with Lactobacillus acidophilus (A) recorded the lowest $\mathrm{pH}$ during the fermentation of yoghurt. The chemical composition of the produced yoghurt indicated slightly decreases in carbohydrates and $\mathrm{pH}$ values, Moreover there were significantly increased in TS, protein, fat and titratable acidity contents during cold storage. On the other hand, WSN (\%), diacetyle ( $\mathrm{ppm})$ and viscosity (cp) significantly increased in the fortified treatments comparing to the unfortified control $\left(\mathrm{C}_{1}\right)$. The total viable cell counts of TBC, LAB, Streptococcus thermophilus and probiotic bacteria $(\log \mathrm{cfu} / \mathrm{ml})$ increased during cold storage through the first 7 days then they decreased thereafter gradually till the end of storage period. Generally, it can be found that enriched synbioticdrinkable yoghurt treatments with different probiotic strains and oat had higher viable counts compared to control $\left(\mathrm{C}_{1}\right)$; there was an improvement of sensory properties by adding probiotic bacteria and oat.
\end{abstract}

Key Words: Synbiotic-drinkable yoghurt, probiotic bacteria, oat, acid development, physico-chemical, microbiological properties.

\section{Introduction}

Nowadays, people are becoming health conscious and moving to foods which gives health and nutritional benefits with good taste. With the increasing interest of consumers towards nutraceuticals and functional foods, there is a limited number of presences of fortified milk and yoghurt containing bioactive compounds. There are very less dairy based functional products are present in the market, but the consumers are raising demand for dairy products with functional properties, and this demand for functional foods is becoming the key factor for driving value sales growth in developed markets. Many bioactive ingredients such as omega 3 -fatty acids, plant sterols, probiotic, prebiotics and bioactive peptides are added in functional dairy products with the purpose of delivering specific health benefits (Tiwari et al., 2017).

The addition of probiotic bacteria to yoghurt improves its functionality and health effects. Probiotics such as Lactobacillus and Bifidobacterium ssp. are bacterial members of the normal human intestinal flora that exert several beneficial effects on human health and well-being. The efficiency ofadded probiotic bacteria depends on dose level and their viability must be maintained throughout storage, and they must survive the gut environment (Aryanaet al., 2007).

Oat, unlike other cereals has received considerable interest in recent years as delivery vehicles for probiotics due to their high content of soluble and insoluble fibers. Oat is an excellent source of soluble fiber $\beta$-glucan and the content of $\beta$ glucan in oat is in the range of 3-7\%. Oat, due to the presence of nutrients, shows the high ferment ability upon applying probiotic lactic acid bacteria. Oat products that contain probiotic and prebiotic are more beneficial than other oat foods (Tiwari et al., 2019).

Therefore, the present study was aimed to make synbiotic-drinkable yoghurt with several new probiotic strains and enriched with $1 \%$ oat and studying the physico-chemical, rheological, microbiological and sensorial properties of produced synbiotic-drinkable yoghurt during cold storage.

\section{Materials and Methods}

\section{Materials:}

Fresh mixed milk (cow's and buffalo's, 1:1) were obtained from the herd of Agriculture Faculty, Benha University, Egypt. Freeze dried conventional yoghurt starter culture (FD-DVS YC-X11-Yo-Flex) containing Lactobacillus delbrueckii ssp. bulgaricus and Streptococcus thermophilus (1:1) was obtained from Chr.Hansen's Laboratories, Copenhagen, Denmark and purchased from MIFAD Company, Egypt. Lactobacillus plantarum ATCC 14917 was obtained from National Research Center, Giza, Egypt. Lactobacillus acidophilus BfEL 92015 and Lactobacillus casei BfEL 92040 were obtained friendly from Institute of Microbiology, Federal Research Center for Nutrition and Food, Kiel, Germany. Bifidobacterium breve Iso 8 was isolated from infants (Ismail, 2007). White oat flakes whole 
grain (DOBELLA), originated by European Union and imported from Elmashreq-gardens Company, Cairo, Egypt and was purchased from local market.

\section{Methods:}

Preparation of the Synbiotic-drinkable yoghurt:

Fresh mixed cow's and buffalo's milk (1:1) was standardized to $\sim 4.5 \%$ fat, $1 \%$ oat was added, heated to $90^{\circ} \mathrm{C}$ for $10 \mathrm{~min}$, immediately cooled down to $42^{\circ} \mathrm{C}$, then divided into seven equally portions, $1.5 \%$ probiotics were added as follows:

$\mathrm{C}_{1}$ : Control without probiotic strains or oat. O: Control with $1 \%$ oat.

A: $1.5 \%$ Lb. acidophilus $+1 \%$ oat.

B: $1.5 \%$ Bifido. breve $+1 \%$ oat.

C: $1.5 \%$ Lb. casei+ $1 \%$ oat.

P: $1.5 \%$ Lb. plantarum $+1 \%$ oat.

M: $1.5 \%$ of ( $L b$. acidophilus + Bifido. breve $+L b$. casei + Lb. plantarum;1:1:1:1) +1\% oat.

All treatments (except treatments $\mathrm{C}_{1}$ and $\mathrm{O}$ ) were inoculated with probiotics, and incubated at $42^{\circ} \mathrm{C}$ for one hour. The Synbiotic-drinkable yoghurt was then prepared according to Tamime\& Robinson (1999). In the next day, yoghurt was mightily stirred then filled into sterilized glass bottles $(200 \mathrm{ml})$. All treatments were analyzed for physical, chemical, rheological, microbiological and sensory properties when fresh and after 7,14 and 21 days.

\section{Analytical tests:}

Physico-chemical properties:

Total solids, protein, fat, water soluble nitrogen and carbohydrates contents were determined according to the methodology mentioned in AOAC, (2012). Titratable acidity was determined according to BSI,(2010). $\mathrm{pH}$ values were measured using a digital laboratory $\mathrm{pH}$ meter (model HANNA pH 213 instruments) with combined glass electrode according to the methods of BSI, (1985). Total volatile fatty acid (TVFA) content was determined by the direct distillation method as described by Kosikowski,(1984). Acetaldehyde and diacetyl contents were determined according to Lees \&Jago (1969) and (1970), respectively.

\section{Rheological analysis:}

Water holding capacity was measured by a centrifuge method according to a modified method of Keogh \&O'Kennedy (1998). The apparent viscosity (centi poise) was measured using Brookfield Engineering Labs DV III ultra rheometer, Inc. Stoughton, MA, USA, according to Petersen et al., (2000).

\section{Microbiological examinations:}

Total bacterial count (TBC) for the produced yoghurt samples were done according to APHA, (2004). Lactic acid bacterial count (LAB) was enumerated according to Elliker et al., (1956). Str. thermophilus was counted on the M17 agar medium supplemented with $0.5 \%$ lactose according to de Souza et al., (2008). Yeast and moulds counts were enumerated as described by APHA, (2004). Colifrom bacteria group was tested as suggested by the BSI, (1993). Spore-forming bacterial counts were enumerated on plat count agar medium as given by Marshall (2005). Bifidobacterium ssp. was counted by using modified MRS agar supplemented with $0.05 \%$ L-cystein and $0.3 \%$ lithium chloride according to Dave \& Shah (1996). Lb. plantarum count was done according to Bujalance et al., (2006) on $\boldsymbol{L} \boldsymbol{b}$. plantarum selective medium (LPSM). MRSclindamycin agar was used for counting of $\boldsymbol{L} \boldsymbol{b}$. acidophilus followed by anaerobic incubation as described by Van de Casteele et al., (2006). $\boldsymbol{L} \boldsymbol{b}$. casei count was performed using MRS-vancomycin agar according to the method described by Ong $\boldsymbol{\&}$ Shah (2009). The plates of Bifidobacteria and Lactobacilli strains were anaerobically incubated at $37^{\circ} \mathrm{C}$ for 3-4days in anaerobic jars (with $\mathrm{CO}_{2}$ injection).

\section{Sensory evaluation:}

Synbiotic-drinkable yoghurt was judged when fresh, and during storage period according to Tamime\& Robinson (1999).

\section{Statistical analysis:}

Statistical analysis was performed according to statistical Analysis System SAS, (2008) using General Linear Model (GLM) with main effect of treatment. Duncan's multiple range was used to separate among of three replicates at $(P<0.05)$.

\section{Results and Discussion}

Physico-chemical analysis of raw milk and heat treated milk used in production synbioticdrinkable yoghurt:

Results recorded in Table (1) illustrate the physico-chemical parameters of raw cow's and buffalo's mixed milk (1:1), heat treated mixed milk (1:1) and heat treated mixed milk enriched with oatused in production of Synbiotic-drinkable yoghurts. According to the obtained results, it could be observed that after heat treatment of mixed cows and buffalo's milk (1:1); the chemical components increased. Also, addition of oat to the mixed milk increased all the milk components. This may be due to loss of some moisture content and the higher dry matter of oat as recommended by Tiwari et al.,(2017).

\section{The pH development:}

The $\mathrm{pH}$ development of probiotic strains used in production Synbiotic-drinkable yoghurt is presented in Fig. (1), it could be noticed that treatment (A) with Lactobacillus acidophilus recorded the lowest $\mathrm{pH}$, 
while control sample $\left(\mathrm{C}_{1}\right)$ without probiotic strains or oat and treatment (B) with Bifidobacterium breve recorded the highest $\mathrm{pH}$ values during the fermentation of yoghurt. After 4 hours of incubation $\left(42^{\circ} \mathrm{C}\right), \mathrm{pH}$ ranged from 4.65 to 4.71 , for treatment (A) and (B), respectively. A rapid decrease in $\mathrm{pH}$ is essential for coagulation and prevention or reduction of growth of undesirable microorganisms. Generally, the desirable properties for industrial LAB or probiotic strains are the abilities to rapidly and completely convert the raw materials into lactic acid with minimal nutritional requirements. Also, the oat added had a strong effect on the acidification rate (Akabanda et al., 2014).

Table 1. Physico-chemical analysis of raw mixed and heat treated mixed milk with and without oat used in production of synbiotic-drinkable yoghurt.

\begin{tabular}{lccccc}
\hline Parameter & Raw cow's & Raw buffaloes & Raw mixed & Heat & Heat treated \\
\hline T.S (\%) & 11.95 & 15.04 & 13.63 & 13.79 & 14.09 \\
Ash (\%) & 0.74 & 0.76 & 0.75 & 0.76 & 0.78 \\
pH value & 6.75 & 6.52 & 6.64 & 6.66 & 6.64 \\
Acidity (\%) & 0.16 & 0.18 & 0.17 & 0.15 & 0.16 \\
Fat (\%) & 3.30 & 6.00 & 4.60 & 4.63 & 4.65 \\
Protein (\%) & 3.15 & 3.42 & 3.27 & 3.32 & 3.35 \\
Carbohydrates (\%) & 4.76 & 4.86 & 5.01 & 5.09 & 5.31 \\
Specific gravity & 1.032 & 1.036 & 1.033 & 1.034 & 1.035 \\
\hline
\end{tabular}

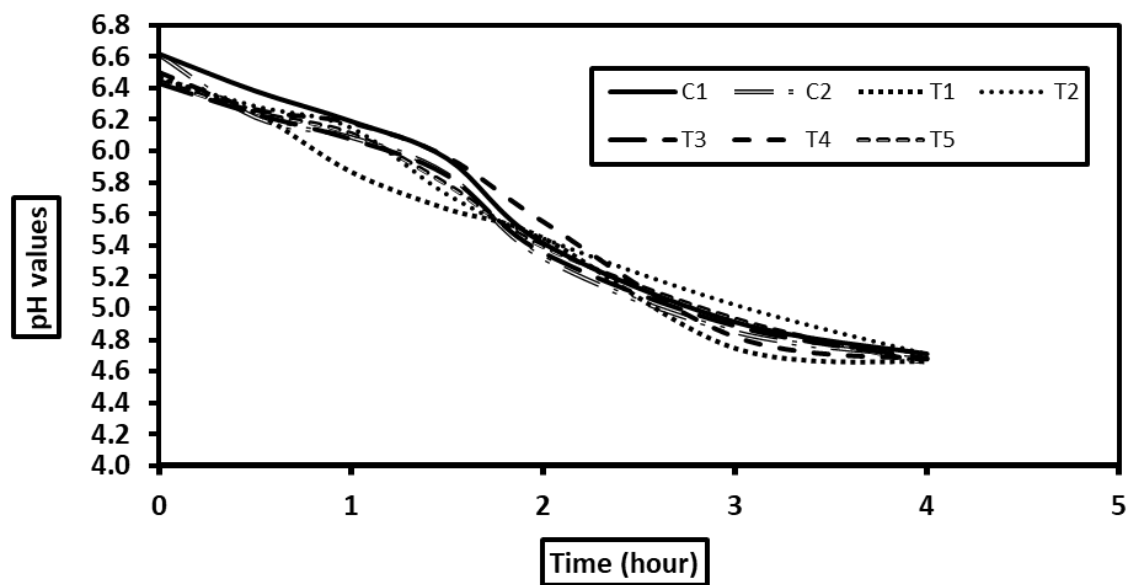

Fig. 1: The pH development of probiotic bacteria used in production of Synbiotic-drinkable yoghurt

\section{Physico-chemical properties:}

The physico-chemical properties of Synbioticdrinkable yoghurt fortified with different probiotic strains and oat when fresh and during storage period at $5^{\circ} \mathrm{C}$ up to 21 days are shown in Table (2). The results indicated that T.S, protein and fat contents were significantly increased in all Synbioticdrinkable yoghurt treatments during the storage period up to 21 days. These increases ratios are related to partial loss of moisture content in all yoghurt treatments through cold storage periods. Similar trends were recorded by El-Alfy et al., (2018). As recorded in the previous results, the adding of oat as prebiotic to different Synbioticdrinkable yoghurt caused significantly increases in T.S, protein, fat and ash contents; this is may be due to the higher dry matter of oat. Our results are in agreement with Tiwari et al., (2017). Carbohydrates
(CHO)values gradually decreased during the storage period, this reduction related to $\mathrm{CHO}$ fermentation by microbial activity and accelerated hydrolysis of insoluble sugars, also, treatments enriched with oat have higher $\mathrm{CHO}$ content comparing with control $\mathrm{C}_{1}$ (without oat). Similar results were recorded by ElKholy\&Mahrous (2015). The titratable acidity significantly increased during cold storage period up to 21 days. This increase is due to the activity and growth of lactic acid bacteria which are tending to increase the acidity and the presence of prebiotics will lead to controlling the process of postacidification among the different probiotic strains. Treatments fortified with Bifibo. breve (B) and fortified with $\boldsymbol{L} \boldsymbol{b}$. plantarum (P) gained the lowest changes in acidity, whereas treatment (A) with $\boldsymbol{L} \boldsymbol{b}$. acidophilus gained the highest values along storage periods. These results are in agreement with Yadav 
et al., (2007) and Bandiera et al., (2013). The $\mathrm{pH}$ values revealed an opposite trend of acidity, decreased throughout the storage periods but did not fall below $\mathrm{pH} 4.0$, which is generally considered detrimental to the survival of probiotic bacteria.

Soluble indices:
The results in Table (3) showed that the water soluble nitrogen (WSN) content significantly increased in the fortified treatments with different probiotic strains and oat comparing to the unfortified control $\left(\mathrm{C}_{1}\right)$ when fresh and by extending the storage period. At the end of storage period ( 21 days) the treatment $(\mathrm{P})$ with $\boldsymbol{L b}$. plantarum and the treatment (B) with Bifido. breve had the highest WSN contents $(0.235 \%)$ and $(0.229 \%)$, consecutively.

Table 2. Physico-chemical properties of synbiotic-drinkable yoghurt fortified with different probiotic strains and oat when fresh and during storage at $5^{\circ} \mathrm{C}$ up to 21 days.

\begin{tabular}{|c|c|c|c|c|c|c|c|}
\hline \multirow{2}{*}{$\begin{array}{c}\text { Storage } \\
\text { period } \\
\text { (days) }\end{array}$} & \multicolumn{7}{|c|}{ T.S (\%) } \\
\hline & $\mathbf{C}_{1}$ & $\mathbf{O}$ & $\mathbf{A}$ & B & C & $\mathbf{P}$ & $\mathbf{M}$ \\
\hline Fresh & $13.43^{\mathrm{Aa}}$ & $14.37^{\mathrm{Ab}}$ & $14.12^{\mathrm{Ab}}$ & $14.02^{\mathrm{Ab}}$ & $14.07^{\mathrm{Ab}}$ & $14.08^{\mathrm{Ab}}$ & $13.99^{\mathrm{Ab}}$ \\
\hline 7 & $13.59^{\mathrm{Aa}}$ & $14.44^{\mathrm{Ab}}$ & $14.30^{\mathrm{Ab}}$ & $14.08^{\mathrm{Ab}}$ & $14.19^{\mathrm{Ab}}$ & $14.24^{\mathrm{Ab}}$ & $14.13^{\mathrm{Ab}}$ \\
\hline 14 & $13.65^{\mathrm{Aa}}$ & $14.59^{\mathrm{Ab}}$ & $14.37^{\mathrm{Ab}}$ & $14.27^{\mathrm{Ab}}$ & $14.25^{\mathrm{Ab}}$ & $14.35^{\mathrm{Ab}}$ & $14.16^{\mathrm{Ab}}$ \\
\hline \multirow[t]{2}{*}{21} & $13.70^{\mathrm{Aa}}$ & $14.61^{\mathrm{Ab}}$ & $14.39^{\mathrm{Ab}}$ & $14.40^{\mathrm{Ab}}$ & $14.31^{\mathrm{Ab}}$ & $14.38^{\mathrm{Ab}}$ & $14.28^{\mathrm{Ab}}$ \\
\hline & \multicolumn{7}{|c|}{ Protein (\%) } \\
\hline Fresh & $3.29^{\mathrm{Cb}}$ & $3.38^{\mathrm{Ca}}$ & $3.33^{\mathrm{Cab}}$ & $3.32^{\mathrm{Cab}}$ & $3.33^{\mathrm{Cb}}$ & $3.35^{\mathrm{Cab}}$ & $3.33^{\mathrm{Cab}}$ \\
\hline 7 & $3.42^{\mathrm{Bb}}$ & $3.47^{\mathrm{Ba}}$ & $3.43^{\mathrm{Bab}}$ & $3.46^{\mathrm{Bab}}$ & $3.43^{\mathrm{Bb}}$ & $3.46^{\mathrm{Bab}}$ & $3.49^{\mathrm{Bab}}$ \\
\hline 14 & $3.49^{\mathrm{Ab}}$ & $3.59^{\mathrm{Aa}}$ & $3.50^{\mathrm{Aab}}$ & $3.56^{\mathrm{Aab}}$ & $3.51^{\mathrm{Ab}}$ & $3.52^{\mathrm{Aab}}$ & $3.54^{\mathrm{Aab}}$ \\
\hline \multirow[t]{2}{*}{21} & $3.51^{\mathrm{Ab}}$ & $3.68^{\mathrm{Aa}}$ & $3.59^{\mathrm{Aab}}$ & $3.57^{\mathrm{Aab}}$ & $3.52^{\mathrm{Ab}}$ & $3.56^{\mathrm{Aab}}$ & $3.55^{\mathrm{Aab}}$ \\
\hline & \multicolumn{7}{|c|}{ Fat $(\%)$} \\
\hline Fresh & $4.57^{\mathrm{Ca}}$ & $4.58^{\mathrm{Ca}}$ & $4.60^{\mathrm{Ca}}$ & $4.65^{\mathrm{Ca}}$ & $4.58^{\mathrm{Ca}}$ & $4.63^{\mathrm{Ca}}$ & $4.65^{\mathrm{Ca}}$ \\
\hline 7 & $4.65^{\mathrm{BCa}}$ & $4.67^{\mathrm{BCa}}$ & $4.66^{\mathrm{BCa}}$ & $4.73^{\mathrm{BCa}}$ & $4.73^{\mathrm{BCa}}$ & $4.65^{\mathrm{BCa}}$ & $4.69^{\mathrm{BCa}}$ \\
\hline 14 & $4.72^{\mathrm{ABa}}$ & $4.75^{\mathrm{ABa}}$ & $4.70^{\mathrm{Aba}}$ & $4.83^{\mathrm{ABa}}$ & $4.75^{\mathrm{ABa}}$ & $4.80^{\mathrm{ABa}}$ & $4.78^{\mathrm{ABa}}$ \\
\hline \multirow[t]{2}{*}{21} & $4.78^{\mathrm{Aa}}$ & $4.80^{\mathrm{Aa}}$ & $4.85^{\mathrm{Aa}}$ & $4.88^{\mathrm{Aa}}$ & $4.82^{\mathrm{Aa}}$ & $4.87^{\mathrm{Aa}}$ & $4.91^{\mathrm{Aa}}$ \\
\hline & \multicolumn{7}{|c|}{ Carbohydrate (CHO \%) } \\
\hline Fresh & $4.87^{\mathrm{Ab}}$ & $5.66^{\mathrm{Aa}}$ & $5.49^{\mathrm{Aa}}$ & $5.34^{\mathrm{Aab}}$ & $5.45^{\text {Aab }}$ & $5.38^{\mathrm{Aab}}$ & $5.30^{\mathrm{Aab}}$ \\
\hline 7 & $4.79^{\mathrm{Ab}}$ & $5.55^{\mathrm{Aa}}$ & $5.54^{\mathrm{Aa}}$ & $5.15^{\text {Aab }}$ & $5.27^{\mathrm{Aab}}$ & $5.39^{\mathrm{Aab}}$ & $5.25^{\mathrm{Aab}}$ \\
\hline 14 & $4.69^{\mathrm{Ab}}$ & $5.51^{\mathrm{Aa}}$ & $5.42^{\mathrm{Aa}}$ & $5.13^{\mathrm{Aab}}$ & $5.22^{\mathrm{Aab}}$ & $5.26^{\mathrm{Aab}}$ & $5.10^{\mathrm{Aab}}$ \\
\hline \multirow[t]{2}{*}{21} & $4.65^{\mathrm{Ab}}$ & $5.35^{\mathrm{Aa}}$ & $5.19^{\text {Aa }}$ & $5.17^{\text {Aab }}$ & $5.21^{\mathrm{Aab}}$ & $5.18^{\mathrm{Aab}}$ & $5.05^{\text {Aab }}$ \\
\hline & \multicolumn{7}{|c|}{ Titratable acidity $(\%)$} \\
\hline Fresh & $0.64^{\mathrm{Dbcd}}$ & $0.66^{\mathrm{Dabc}}$ & $0.69^{\mathrm{Da}}$ & $0.65^{\mathrm{Dd}}$ & $0.67^{\text {Dabc }}$ & $0.64^{\mathrm{Dcd}}$ & $0.68^{\mathrm{Dab}}$ \\
\hline 7 & $0.69^{\mathrm{Cbcd}}$ & $0.72^{\mathrm{Cabc}}$ & $0.77^{\mathrm{Ca}}$ & $0.69^{\mathrm{Cd}}$ & $0.72^{\text {Cabc }}$ & $0.69^{\mathrm{Ccd}}$ & $0.73^{\mathrm{Cab}}$ \\
\hline 14 & $0.77^{\mathrm{Bbcd}}$ & $0.79^{\mathrm{Babc}}$ & $0.83^{\mathrm{Ba}}$ & $0.71^{\mathrm{Bd}}$ & $0.78^{\mathrm{Babc}}$ & $0.73^{\mathrm{Bcd}}$ & $0.79^{\mathrm{Bab}}$ \\
\hline \multirow[t]{2}{*}{21} & $0.82^{\mathrm{Abcd}}$ & $0.84^{\mathrm{Aabc}}$ & $0.90^{\mathrm{Aa}}$ & $0.73^{\mathrm{Ad}}$ & $0.84^{\mathrm{Acbc}}$ & $0.74^{\text {Acd }}$ & $0.83^{\mathrm{Aab}}$ \\
\hline & \multicolumn{7}{|c|}{ pH values } \\
\hline Fresh & $4.61^{\mathrm{Aab}}$ & $4.57^{\mathrm{Ab}}$ & $4.56^{\mathrm{Ab}}$ & $4.61^{\mathrm{Aa}}$ & $4.58^{\mathrm{Aab}}$ & $4.59^{\mathrm{Aa}}$ & $4.58^{\mathrm{Ab}}$ \\
\hline 7 & $4.32^{\mathrm{Bab}}$ & $4.29^{\mathrm{Bb}}$ & $4.31^{\mathrm{Bb}}$ & $4.35^{\mathrm{Ba}}$ & $4.33^{\mathrm{Bab}}$ & $4.36^{\mathrm{Ba}}$ & $4.22^{\mathrm{Bb}}$ \\
\hline 14 & $4.16^{\mathrm{Cab}}$ & $4.13^{\mathrm{Cb}}$ & $4.12^{\mathrm{Cb}}$ & $4.17^{\mathrm{Ca}}$ & $4.14^{\mathrm{Cab}}$ & $4.16^{\mathrm{Ca}}$ & $4.14^{\mathrm{Cb}}$ \\
\hline 21 & $4.05^{\mathrm{Dab}}$ & $4.04^{\mathrm{Db}}$ & $4.02^{\mathrm{Db}}$ & $4.09^{\mathrm{Da}}$ & $4.04^{\mathrm{Dab}}$ & $4.13^{\mathrm{Da}}$ & $4.06^{\mathrm{Db}}$ \\
\hline
\end{tabular}

$\mathrm{C}_{1}$ : Control without probiotic strains or oat. $\quad$ O: Control with $1 \%$ oat. $\quad$ A: $1.5 \%$ Lb. acidophilus $+1 \%$ oat. $\begin{array}{lll}\text { B: } 1.5 \% \text { Bifido. breve }+1 \% \text { oat. } & \text { C: } 1.5 \% \text { Lb. case }+1 \% \text { oat. } & \text { P: } 1.5 \% \text { Lb. plantarum }+1 \% \text { oat. }\end{array}$ M: $1.5 \%$ of (Lb. acidophilus + Bifido. breve $+\boldsymbol{L}$ b. case $+\boldsymbol{L}$ b. plantarum; $1: 1: 1: 1)+1 \%$ oat.

A, B, C: Means with same letter among treatments in the same storage period are not significantly different $(p<0.05)$. $\mathrm{a}, \mathrm{b}, \mathrm{c}$ : Means with same letter for same treatment during storage period are not significantly different $(p<0.05)$. 
Table 3. Soluble indices of Synbiotic-drinkable yoghurt fortified with different probiotic strains and oat when fresh and during storage at $5^{\circ} \mathrm{C}$ up to 21 days.

\begin{tabular}{|c|c|c|c|c|c|c|c|}
\hline \multirow{2}{*}{$\begin{array}{l}\text { Storage } \\
\text { period } \\
\text { (days) }\end{array}$} & \multicolumn{7}{|c|}{ Water soluble nitrogen (WSN \%) } \\
\hline & $\mathbf{C}_{1}$ & $\mathbf{O}$ & $\mathbf{A}$ & B & $\mathbf{C}$ & $\mathbf{P}$ & $\mathbf{M}$ \\
\hline Fresh & $0.135^{\mathrm{Dd}}$ & $0.157^{\mathrm{Dc}}$ & $0.163^{\mathrm{Dbc}}$ & $0.170^{\mathrm{Dab}}$ & $0.169^{\mathrm{Dab}}$ & $0.172^{\mathrm{Da}}$ & $0.168^{\mathrm{Dab}}$ \\
\hline 7 & $0.143^{\mathrm{Cd}}$ & $0.166^{\mathrm{Cc}}$ & $0.178^{\mathrm{Cbc}}$ & $0.195^{\mathrm{Cab}}$ & $0.188^{\mathrm{Cab}}$ & $0.195^{\mathrm{Ca}}$ & $0.197^{\mathrm{Cab}}$ \\
\hline 14 & $0.149^{\mathrm{Bd}}$ & $0.175^{\mathrm{Bc}}$ & $0.191^{\mathrm{Bbc}}$ & $0.211^{\mathrm{Bab}}$ & $0.204^{\mathrm{Bab}}$ & $0.218^{\mathrm{Ba}}$ & $0.210^{\mathrm{Bab}}$ \\
\hline \multirow[t]{2}{*}{21} & $0.165^{\mathrm{Ad}}$ & $0.194^{\mathrm{Ac}}$ & $0.204^{\mathrm{Abc}}$ & $0.229^{\text {Aab }}$ & $0.219^{\mathrm{Aab}}$ & $0.235^{\mathrm{Aa}}$ & $0.223^{\mathrm{Aab}}$ \\
\hline & \multicolumn{7}{|c|}{ TVFA (ml 0.1NNaOH/100g) } \\
\hline Fresh & $3.15^{\mathrm{De}}$ & $3.75^{\mathrm{Dd}}$ & $4.11^{\mathrm{Dd}}$ & $4.91^{\mathrm{Dbc}}$ & $4.70^{\mathrm{Dc}}$ & $5.13^{\mathrm{Da}}$ & $5.08^{\mathrm{Dab}}$ \\
\hline 7 & $5.20^{\mathrm{Ce}}$ & $5.67^{\mathrm{Cd}}$ & $6.13^{\mathrm{Cd}}$ & $6.66^{\mathrm{Cbc}}$ & $6.90^{\mathrm{Cc}}$ & $7.67^{\mathrm{Ca}}$ & $7.23^{\mathrm{Cab}}$ \\
\hline 14 & $6.44^{\mathrm{Be}}$ & $7.75^{\mathrm{Bd}}$ & $7.71^{\mathrm{Bd}}$ & $7.54^{\mathrm{Bbc}}$ & $8.05^{\mathrm{Bc}}$ & $9.50^{\mathrm{Ba}}$ & $9.74^{\mathrm{Bab}}$ \\
\hline \multirow[t]{2}{*}{21} & $7.76^{\mathrm{Ae}}$ & $8.50^{\mathrm{Ad}}$ & $8.75^{\mathrm{Ad}}$ & $11.97^{\mathrm{Abc}}$ & $10.44^{\mathrm{Ac}}$ & $12.21^{\mathrm{Aa}}$ & $11.13^{\mathrm{Aab}}$ \\
\hline & \multicolumn{7}{|c|}{ Acetaldehyde (ppm) } \\
\hline Fresh & $12.12^{\mathrm{Ag}}$ & $14.61^{\mathrm{Af}}$ & $15.12^{\mathrm{Ae}}$ & $18.61^{\mathrm{Ad}}$ & $19.40^{\mathrm{Aa}}$ & $18.82^{\mathrm{Ac}}$ & $19.10^{\mathrm{Ab}}$ \\
\hline 7 & $11.32^{\mathrm{Bg}}$ & $13.33^{\mathrm{Bf}}$ & $13.40^{\mathrm{Be}}$ & $17.35^{\mathrm{Bd}}$ & $18.05^{\mathrm{Ba}}$ & $18.45^{\mathrm{Bc}}$ & $18.63^{\mathrm{Bb}}$ \\
\hline 14 & $10.45^{\mathrm{Cg}}$ & $11.96^{\mathrm{Cf}}$ & $12.21^{\mathrm{Ce}}$ & $16.46^{\mathrm{Cd}}$ & $17.45^{\mathrm{Ca}}$ & $16.32^{\mathrm{Cc}}$ & $16.92^{\mathrm{Cb}}$ \\
\hline \multirow[t]{2}{*}{21} & $8.60^{\mathrm{Dg}}$ & $10.65^{\mathrm{Df}}$ & $10.75^{\mathrm{De}}$ & $16.00^{\mathrm{Dd}}$ & $16.32^{\mathrm{Da}}$ & $15.39^{\mathrm{Dc}}$ & $15.61^{\mathrm{Db}}$ \\
\hline & \multicolumn{7}{|c|}{ Diacetyl (ppm) } \\
\hline Fresh & $7.15^{\mathrm{Dd}}$ & $8.21^{\mathrm{Dc}}$ & $8.25^{\mathrm{Dc}}$ & $8.51^{\mathrm{Db}}$ & $9.11^{\mathrm{Db}}$ & $8.68^{\mathrm{Da}}$ & $9.26^{\mathrm{Da}}$ \\
\hline 7 & $7.93^{\mathrm{Cd}}$ & $9.12^{\mathrm{Cc}}$ & $8.95^{\mathrm{Cc}}$ & $9.15^{\mathrm{Cb}}$ & $10.25^{\mathrm{Cb}}$ & $9.65^{\mathrm{Ca}}$ & $10.57^{\mathrm{Ca}}$ \\
\hline 14 & $8.16^{\mathrm{Bd}}$ & $9.66^{\mathrm{Bc}}$ & $9.56^{\mathrm{Bc}}$ & $11.11^{\mathrm{Bb}}$ & $11.26^{\mathrm{Bb}}$ & $11.23^{\mathrm{Ba}}$ & $12.06^{\mathrm{Ba}}$ \\
\hline 21 & $8.25^{\mathrm{Ad}}$ & $10.21^{\mathrm{Ac}}$ & $10.24^{\mathrm{Ac}}$ & $12.54^{\mathrm{Ab}}$ & $11.98^{\mathrm{Ab}}$ & $12.60^{\mathrm{Aa}}$ & $12.58^{\mathrm{Aa}}$ \\
\hline
\end{tabular}

$\mathrm{C}_{1}$ : Control without probiotic strains or oat. $\mathrm{O}$ : Control with $1 \%$ oat. A: $1.5 \%$ Lb. acidophilus $+1 \%$ oat. B: $1.5 \%$ Bifido. breve $+1 \%$ oat. $\quad$ C: $1.5 \%$ Lb. casei $+1 \%$ oat. $\quad$ P: $1.5 \%$ Lb. plantarum $+1 \%$ oat.

M: $1.5 \%$ of (Lb. acidophilus + Bifido. breve + Lb. casei + Lb. plantarum $; 1: 1: 1: 1)+1 \%$ oat.

A, B, C: Means with same letter among treatments in the same storage period are not significantly different $(p<0.05)$. $\mathrm{a}, \mathrm{b}, \mathrm{c}$ : Means with same letter for same treatment during storage period are not significantly different $(p<0.05)$.

This increase in WSN values could be due to the protein breakdown in the yoghurt by milk enzymes and other microbial activities (El-Kadi et al., 2017). There was significantly increases of TVFA content of all treatments as storage period progressed up to 21 days reaching the maximum values $7.76,8.50$, $8.75, \quad 11.97, \quad 10.44, \quad 12.21$ and $11.13 \mathrm{ml}$ $0.1 \mathrm{NNaOH} / 100 \mathrm{~g}$ for $\mathrm{C}_{1}, \mathrm{O}, \mathrm{A}, \mathrm{B}, \mathrm{C}, \mathrm{P}$ and $\mathrm{M}$, at the end of storage period, in the same previous order. This increase may be due to the ability of starter culture specially proteolytic and lipolytic bacteria to convert lactic acid, citrate, fat and protein into volatile compounds. These findings are consistent with El-Alfy et $\boldsymbol{a l}$., (2018). The synbiotic-drinkable yoghurt treatments recorded higher values of TVFA compared to the controls (Rodrigues et al., 2012).

The acetaldehyde content (Table 3) of fresh synbiotic-drinkable yoghurt treatments scored a range from 12.12 to $19.40 \mathrm{ppm}$, while diacetyl content ranged from 7.15 to $9.26 \mathrm{ppm}$. As prolonging the cold storage of Synbiotic-drinkable yoghurt treatments, the acetaldehyde content of all treatments significantly decreased to range from 8.60 to 16.32 ppm, while diacetyl content of all yoghurt treatments had an opposite trend to that of acetaldehyde, as it significantly increased along cold storage period to have a range from 8.25 to $12.60 \mathrm{ppm}$ at the experimental end (21 days). Similar results were found by Yilmaz-Ersan \&Kurdal (2014). The acetaldehyde and diacetyl contents were significantly higher in synbiotic-drinkable bio- yoghurt treatments enriched with different probiotic strains and oat. These might be due to the metabolism of probiotic bacteria and the compounds of oat stimulated the starter activity. Similar trend was obtained by Bisar et al., (2015) and El-Batawy \& Khalil (2018).

\section{Rheological properties:}

Results in Table (4) revealed that the viscosity values (cp) of fresh treatments were 71.11, 245.17, $102.71,113.03,135.84,129.57$ and $143.36 \mathrm{cp}$ for $\mathrm{C}_{1}$, $\mathrm{O}, \mathrm{A}, \mathrm{B}, \mathrm{C}, \mathrm{P}$ and $\mathrm{M}$, respectively. These values significantly increased during cold storage period. Such values increased in stored drinkable yoghurt to be $121.56,364.00,137.38,176.85,183.06,199.56$ and $215.69 \mathrm{cp}$ at the end of storage period, by the same previous order. The cooling and storage process after fermentation increased viscosity caused by protein hydration and compaction of yoghurt gel structure also, may be due primarily related to their total solids, protein content and titratable acidity of yoghurt treatments during storage. These results are 
in accordance with Astawan et al., (2012). Furthermore, the addition of oat significantly increased the viscosity of synbiotic-drinkable yoghurt treatments as it contains higher amount of starch content and the gelatinization of oat was occurred during heating and storage. Similar results are given by Guler-Akin et al., (2016) and Tiwari et al., (2017).

Table 4. Rheological properties of synbiotic-drinkable yoghurt fortified with different probiotic strains and oat when fresh and during storage at $5^{\circ} \mathrm{C}$ up to 21 days.

\begin{tabular}{|c|c|c|c|c|c|c|c|}
\hline \multirow{2}{*}{$\begin{array}{l}\text { Storage } \\
\text { period } \\
\text { (days) }\end{array}$} & \multicolumn{7}{|c|}{ Apparent viscosity (cp) } \\
\hline & $\mathbf{C}_{1}$ & $\mathbf{O}$ & $\mathbf{A}$ & B & $\mathbf{C}$ & $\mathbf{P}$ & $\mathbf{M}$ \\
\hline Fresh & $71.11^{\mathrm{Bc}}$ & $245.17^{\mathrm{Ba}}$ & $102.71^{\mathrm{Bbc}}$ & $113.03^{\mathrm{Bbc}}$ & $135.84^{\mathrm{Bbc}}$ & $129.57^{\mathrm{Bbc}}$ & $143.36^{\mathrm{Bb}}$ \\
\hline 7 & $82.10^{\mathrm{ABc}}$ & $269.30^{\mathrm{Aba}}$ & $107.21^{\mathrm{ABbc}}$ & $144.81^{\mathrm{ABbc}}$ & $143.67^{\mathrm{ABbc}}$ & $150.39^{\mathrm{ABbc}}$ & $166.81^{\mathrm{ABb}}$ \\
\hline 14 & $88.93^{\mathrm{ABc}}$ & $348.16^{\mathrm{Aba}}$ & $120.85^{\mathrm{ABbc}}$ & $159.37^{\mathrm{ABbc}}$ & $162.56^{\mathrm{ABbc}}$ & $176.55^{\mathrm{ABbc}}$ & $182.20^{\mathrm{ABb}}$ \\
\hline \multirow[t]{2}{*}{21} & $121.56^{\mathrm{Ac}}$ & $364.00^{\mathrm{Aa}}$ & $137.38^{\mathrm{Abc}}$ & $176.85^{\mathrm{Abc}}$ & $183.06^{\mathrm{Abc}}$ & $199.56^{\mathrm{Abc}}$ & $215.69^{\mathrm{Ab}}$ \\
\hline & \multicolumn{7}{|c|}{ Water holding capacity (WHC \%) } \\
\hline Fresh & $69.61^{\mathrm{Aa}}$ & $71.98^{\mathrm{Aa}}$ & $70.55^{\mathrm{Aa}}$ & $70.18^{\mathrm{Aa}}$ & $70.23^{\mathrm{Aa}}$ & $70.31^{\mathrm{Aa}}$ & $70.40^{\mathrm{Aa}}$ \\
\hline 7 & $64.32^{\mathrm{Ba}}$ & $66.76^{\mathrm{Ba}}$ & $63.25^{\mathrm{Ba}}$ & $67.21^{\mathrm{Ba}}$ & $64.65^{\mathrm{Ba}}$ & $67.64^{\mathrm{Ba}}$ & $66.42^{\mathrm{Ba}}$ \\
\hline 14 & $61.17^{\mathrm{Ca}}$ & $63.51^{\mathrm{Ca}}$ & $61.14^{\mathrm{Ca}}$ & $65.25^{\mathrm{Ca}}$ & $62.13^{\mathrm{Ca}}$ & $65.12^{\mathrm{Ca}}$ & $64.68^{\mathrm{Ca}}$ \\
\hline 21 & $57.35^{\mathrm{Da}}$ & $61.62^{\mathrm{Da}}$ & $57.91^{\mathrm{Da}}$ & $62.31^{\mathrm{Da}}$ & $60.42^{\mathrm{Da}}$ & $62.55^{\mathrm{Da}}$ & $61.12^{\mathrm{Da}}$ \\
\hline
\end{tabular}

$\mathrm{C}_{1}$ : Control without probiotic strains or oat. $\mathrm{O}$ : Control with $1 \%$ oat. A: $1.5 \%$ Lb. acidophilus $+1 \%$ oat. B: $1.5 \%$ Bifido. breve $+1 \%$ oat. $\quad$ C: $1.5 \%$ Lb. casei $+1 \%$ oat. $\quad$ P: $1.5 \%$ Lb. plantarum $+1 \%$ oat. M: $1.5 \%$ of $(\boldsymbol{L b}$. acidophilus + Bifido. breve $+\boldsymbol{L}$ b. case $\boldsymbol{C}+\boldsymbol{L} \boldsymbol{b}$. plantarum $; 1: 1: 1: 1)+1 \%$ oat.

A, B, C: Means with same letter among treatments in the same storage period are not significantly different $(p<0.05)$. a, b, c: Means with same letter for same treatment during storage period are not significantly different $(p<0.05)$.

Concerning the water holding capacity of synbiotic-drinkable yoghurt enriched with different probiotic strains and oat Table (4), the values of fresh treatments ranged between the minimum value $69.91 \%$ for treatment $\left(\mathrm{C}_{1}\right)$ to the maximum value $71.98 \%$ for treatment (O). By advancing cold storage, the values of all treatments significantly decreased as a result of the development of acidity and increasing the total solids through storage. Our results are in full accordance with Narayana\& Gupta(2018). Treatments enriched with oat recorded high WHC compared to control without oat throughout cold storage period. Because they had higher total solids, crude fibres, act as a thickeners that exhibited greater ability to bind water compared to control (Gustaw et al., 2011 and Ladjevardi et al., 2016).

\section{Microbiological aspects:}

The results obtained with respect to total bacterial count (TBC), lactic acid bacteria (LAB) and Streptococcus thermophilus counts $(\log \mathrm{cfu} / \mathrm{ml})$ of synbiotic-drinkable yoghurt treatments enriched with different probiotic strains and oat are shown in Table (5). The initial viability counts increased gradually during cold storage and reaches their maximum counts after 7 days of storage period, then declined up to 21 days. These results might be related to the effect of cold storage, acidity development and the reduction of lactose (as a main source of carbon for the bacteria) on bacterial growth. These results are in agreement with those reported by Sarvari et al., (2014) and Abdou et al., (2015). Generally, it can be found that enriched synbiotic-drinkable yoghurt treatments with different probiotic strains and oat had higher counts compared to control $\left(\mathrm{C}_{1}\right)$, because they contains starter culture and besides to probiotic strains. Also, adding of oat enhanced the counts due to their richness in $\boldsymbol{\beta}$-glucan as a prebiotic agent which is more effective for bacterial survival. These findings are in a harmony with the results obtained by Ladjevardi et al., (2016) and Abou-Dobara $e t$ al., (2017).

The viability of yoghurt bacteria and $\mathrm{pH}$ of the yoghurt had effects on the viability of probiotic bacteria. Moreover, different types of probiotic strains Lactobacillus acidophilus; Bifidobacterium breve; Lactobacillus casei and Lactobacillus plantarum have been added to produce synbioticdrinkable yoghurt. Additionally, by the end of storage of Synbiotic-drinkable yoghurt, there was a decrease of all populations possibly caused by adverse conditions, such as low temperature, acid development along the storage period. The results of probiotic bacterial counts indicated that this product meets the requirements for a product to be called a probiotic functional food; as it have at least $10^{6} \mathrm{cfu}$ $/ \mathrm{ml}$ or $6 \log \mathrm{cfu} / \mathrm{ml}$ of different probiotic strains even after storage (Tiwari et al., 2019). 
For the yeast \& moulds, coliform and sporeforming tests of produced synbiotic-drinkable yoghurt the counts were not detected in all samples either fresh or stored at $5^{\circ} \mathrm{C}$ up to 21 days with exception of control $\left(\mathrm{C}_{1}\right)$ which had $(1.70 \log \mathrm{cfu} / \mathrm{ml})$ for yeast and moulds counts but less than $3 \log \mathrm{cfu}$ $/ \mathrm{ml}$, would imply a serious risk of deterioration. i.e. Off-flavor and gas production which appears in the fermented milk products, and this might be related to the development of acidity and antimicrobial activity of the starter cultures or probiotic bacteria during storage period and also, indicated that yoghurt was produced and packaged under good hygienic conditions. Moreover, after 21 days there were some yeast and moulds counts appeared in all the produced drinkable yoghurt expected of treatment (B) and ranged from 1.70 to $2.81 \mathrm{log} \mathrm{cfu} / \mathrm{ml}$. These results are conformable with that of Astawan et al., (2012) and Gamage et al., (2016).

Table 5. Microbiological aspects $(\log \mathrm{cfu} / \mathrm{ml})$ of synbiotic-drinkable yoghurt fortified with different probiotic strains and oat when fresh and during storage at $5^{\circ} \mathrm{C}$ up to 21 days.

\begin{tabular}{|c|c|c|c|c|c|c|c|}
\hline \multirow{2}{*}{$\begin{array}{c}\text { Storage period } \\
\text { (days) }\end{array}$} & \multicolumn{7}{|c|}{ Total bacterial count (TBC) } \\
\hline & $\mathbf{C}_{1}$ & $\mathbf{O}$ & $\mathbf{A}$ & $\mathbf{B}$ & $\mathbf{C}$ & $\mathbf{P}$ & $\mathbf{M}$ \\
\hline Fresh & 8.32 & 8.36 & 8.38 & 8.45 & 8.42 & 8.50 & 8.51 \\
\hline 7 & 8.58 & 8.63 & 8.62 & 8.67 & 8.61 & 8.74 & 8.71 \\
\hline 14 & 8.47 & 8.50 & 8.43 & 8.54 & 8.50 & 8.62 & 8.63 \\
\hline \multirow[t]{2}{*}{21} & 8.31 & 8.32 & 8.30 & 8.45 & 8.41 & 8.47 & 8.49 \\
\hline & \multicolumn{7}{|c|}{ Lactic acid bacterial count (LAB) } \\
\hline Fresh & 8.12 & 8.15 & 8.11 & 8.20 & 8.24 & 8.22 & 8.21 \\
\hline 7 & 8.24 & 8.29 & 8.29 & 8.32 & 8.38 & 8.35 & 8.36 \\
\hline 14 & 8.20 & 8.27 & 8.16 & 8.28 & 8.31 & 8.29 & 8.26 \\
\hline \multirow[t]{2}{*}{21} & 8.09 & 8.14 & 8.08 & 8.17 & 8.23 & 8.20 & 8.21 \\
\hline & \multicolumn{7}{|c|}{ Streptococcus thermophilus count } \\
\hline Fresh & 7.55 & 7.60 & 7.70 & 7.73 & 7.78 & 7.80 & 7.79 \\
\hline 7 & 7.87 & 7.90 & 8.05 & 8.08 & 7.98 & 8.17 & 8.10 \\
\hline 14 & 7.78 & 7.73 & 7.88 & 7.96 & 7.86 & 8.00 & 7.99 \\
\hline 21 & 7.51 & 7.56 & 7.70 & 7.70 & 7.76 & 7.78 & 7.80 \\
\hline
\end{tabular}

Probiotic bacterial counts

\begin{tabular}{|c|c|c|c|c|c|c|c|c|}
\hline & \multicolumn{2}{|c|}{ Lb. acidophilus } & \multicolumn{2}{|c|}{ Bifido. breve } & \multicolumn{2}{|c|}{ Lb.casei } & \multicolumn{2}{|c|}{ Lb.plantarum } \\
\hline & A & M & B & M & $\mathrm{C}$ & M & $\mathrm{P}$ & M \\
\hline Fresh & 6.02 & 5.85 & 8.51 & 7.40 & 7.51 & 7.43 & 7.83 & 7.71 \\
\hline 7 & 6.49 & 6.36 & 7.83 & 7.75 & 7.95 & 7.77 & 8.14 & 7.95 \\
\hline 14 & 6.43 & 6.26 & 7.77 & 7.72 & 7.90 & 7.74 & 8.05 & 7.89 \\
\hline 21 & 6.21 & 6.18 & 7.74 & 7.54 & 7.74 & 7.66 & 8.04 & 7.85 \\
\hline
\end{tabular}

$\mathrm{C}_{1}$ : Control without probiotic strains or oat. $\mathrm{O}$ : Control with $1 \%$ oat. $\mathrm{A}: 1.5 \%$ Lb. acidophilus $+1 \%$ oat.

B: $1.5 \%$ Bifido. breve $+1 \%$ oat. $\quad$ C: $1.5 \%$ Lb. casei $+1 \%$ oat. $\quad$ P: $1.5 \%$ Lb. plantarum $+1 \%$ oat.

M: $1.5 \%$ of (Lb. acidophilus + Bifido. breve $+\boldsymbol{L}$ b. casei $+\boldsymbol{L b}$. plantarum; 1:1:1:1) +1\% oat.

\section{Sensory evaluation:}

From the overall acceptability side of view Table (6) for fresh treatments, the highest overall acceptabilities were recorded for the treatments (B) made with Bifido. breve (94.93 point) and (P) made with $\boldsymbol{L} \boldsymbol{b}$. plantarum which scored (94.72 point), and the lowest acceptability score (88.91 point) was for the control $\left(\mathrm{C}_{1}\right)$. Generally, the overall acceptability scores of samples significantly increased during cold storage up to 7 days which rated about 90.21 to 96.27 points, and thereafter decreased for all criteria. This could be associated with development of acidity and decreases in acetaldehyde contents. These findings are in the line of Tammam et al., (2011); Delavari et al., (2014) and Yilmaz-Ersan\&Kurdal (2014). 
Table 6. Sensory evaluation of synbiotic-drinkable yoghurt fortified with different probiotic strains and oat when fresh and during storage at $5^{\circ} \mathrm{C}$ up to 21 days.

\begin{tabular}{|c|c|c|c|c|c|c|c|}
\hline \multirow{2}{*}{$\begin{array}{c}\text { Storage } \\
\text { period } \\
\text { (days) }\end{array}$} & \multicolumn{7}{|c|}{ Flavor (50) } \\
\hline & $\mathrm{C}_{1}$ & $\mathbf{O}$ & $\mathbf{A}$ & B & $\mathbf{C}$ & $\mathbf{P}$ & $\mathbf{M}$ \\
\hline Fresh & $45.55^{\mathrm{Bg}}$ & $46.22^{\mathrm{Bf}}$ & $46.52^{\mathrm{Be}}$ & $48.25^{\mathrm{Bb}}$ & $47.90^{\mathrm{Bc}}$ & $48.17^{\mathrm{Ba}}$ & $47.11^{\mathrm{Bd}}$ \\
\hline 7 & $46.23^{\mathrm{Ag}}$ & $46.91^{\mathrm{Af}}$ & $47.14^{\mathrm{Ae}}$ & $48.51^{\mathrm{Ab}}$ & $48.17^{\mathrm{Ac}}$ & $48.83^{\mathrm{Aa}}$ & $47.62^{\mathrm{Ad}}$ \\
\hline 14 & $45.31^{\mathrm{Bg}}$ & $46.24^{\mathrm{Bf}}$ & $46.67^{\mathrm{Be}}$ & $47.92^{\mathrm{Bb}}$ & $47.45^{\mathrm{Bc}}$ & $48.05^{\mathrm{Ba}}$ & $47.56^{\mathrm{Bd}}$ \\
\hline \multirow[t]{2}{*}{21} & $44.13^{\mathrm{Cg}}$ & $45.85^{\mathrm{Cf}}$ & $46.13^{\mathrm{Ce}}$ & $47.34^{\mathrm{Cb}}$ & $46.50^{\mathrm{Cc}}$ & $47.54^{\mathrm{Ca}}$ & $47.13^{\mathrm{Cd}}$ \\
\hline & \multicolumn{7}{|c|}{ Body \& texture (40) } \\
\hline Fresh & $35.14^{\mathrm{Be}}$ & $36.17^{\mathrm{Bd}}$ & $36.24^{\mathrm{Bc}}$ & $37.13^{\mathrm{Ba}}$ & $36.81^{\mathrm{Bb}}$ & $36.94^{\mathrm{Ba}}$ & $36.46^{\mathrm{Bb}}$ \\
\hline 7 & $35.45^{\mathrm{Ae}}$ & $36.90^{\mathrm{Ad}}$ & $36.82^{\mathrm{Ac}}$ & $37.51^{\mathrm{Aa}}$ & $37.20^{\mathrm{Ab}}$ & $37.66^{\mathrm{Aa}}$ & $37.30^{\mathrm{Ab}}$ \\
\hline 14 & $34.53^{\mathrm{Ce}}$ & $35.92^{\mathrm{Cd}}$ & $36.24^{\mathrm{Cc}}$ & $36.74^{\mathrm{Ca}}$ & $36.32^{\mathrm{Cb}}$ & $36.82^{\mathrm{Ca}}$ & $36.31^{\mathrm{Cb}}$ \\
\hline \multirow[t]{2}{*}{21} & $33.61^{\mathrm{De}}$ & $35.23^{\mathrm{Dd}}$ & $35.52^{\mathrm{Dc}}$ & $36.43^{\mathrm{Da}}$ & $35.90^{\mathrm{Db}}$ & $36.55^{\mathrm{Da}}$ & $36.13^{\mathrm{Db}}$ \\
\hline & \multicolumn{7}{|c|}{ Appearance (10) } \\
\hline Fresh & $8.22^{\mathrm{Be}}$ & $8.61^{\mathrm{Bd}}$ & $9.14^{\mathrm{Bc}}$ & $9.55^{\mathrm{Ba}}$ & $9.32^{\mathrm{Bb}}$ & $9.61^{\mathrm{Ba}}$ & $9.23^{\mathrm{Bb}}$ \\
\hline 7 & $8.53^{\mathrm{Ae}}$ & $8.84^{\mathrm{Ad}}$ & $9.25^{\mathrm{Ac}}$ & $9.67^{\mathrm{Aa}}$ & $9.33^{\mathrm{Ab}}$ & $9.78^{\mathrm{Aa}}$ & $9.45^{\mathrm{Ab}}$ \\
\hline 14 & $8.24^{\mathrm{Ce}}$ & $8.71^{\mathrm{Cd}}$ & $8.96^{\mathrm{Cc}}$ & $9.54^{\mathrm{Ca}}$ & $9.21^{\mathrm{Cb}}$ & $9.42^{\mathrm{Ca}}$ & $9.19^{\mathrm{Cb}}$ \\
\hline \multirow[t]{2}{*}{21} & $8.17^{\mathrm{De}}$ & $8.42^{\mathrm{Dd}}$ & $8.84^{\mathrm{Dc}}$ & $9.21^{\mathrm{Da}}$ & $9.12^{\mathrm{Db}}$ & $9.30^{\mathrm{Da}}$ & $9.05^{\mathrm{Db}}$ \\
\hline & \multicolumn{7}{|c|}{ Overall acceptability (100) } \\
\hline Fresh & $88.91^{\mathrm{Be}}$ & $91.00^{\mathrm{Bd}}$ & $91.90^{\mathrm{Bc}}$ & $94.93^{\mathrm{Ba}}$ & $94.03^{\mathrm{Bb}}$ & $94.72^{\mathrm{Ba}}$ & $92.80^{\mathrm{Bb}}$ \\
\hline 7 & $90.21^{\mathrm{Ae}}$ & $92.65^{\mathrm{Ad}}$ & $93.21^{\mathrm{Ac}}$ & $95.69^{\mathrm{Aa}}$ & $94.70^{\mathrm{Ab}}$ & $96.27^{\mathrm{Aa}}$ & $94.37^{\mathrm{Ab}}$ \\
\hline 14 & $88.08^{\mathrm{Ce}}$ & $90.87^{\mathrm{Cd}}$ & $91.87^{\mathrm{Cc}}$ & $94.20^{\mathrm{Ca}}$ & $92.98^{\mathrm{Cb}}$ & $94.29^{\mathrm{Ca}}$ & $93.06^{\mathrm{Cb}}$ \\
\hline 21 & $85.91^{\mathrm{De}}$ & $89.50^{\mathrm{Dd}}$ & $90.49^{\mathrm{Dc}}$ & $92.98^{\mathrm{Da}}$ & $91.52^{\mathrm{Db}}$ & $93.39^{\mathrm{Da}}$ & $92.31^{\mathrm{Db}}$ \\
\hline
\end{tabular}

$\mathrm{C}_{1}$ : Control without probiotic strains or oat. O: Control with $1 \%$ oat. $\mathrm{A}: 1.5 \%$ Lb. acidophilus $+1 \%$ oat.

B: $1.5 \%$ Bifido. breve $+1 \%$ oat. $\quad$ C: $1.5 \%$ Lb. casei $+1 \%$ oat. $\quad$ P: $1.5 \%$ Lb. plantarum $+1 \%$ oat.

M: $1.5 \%$ of (Lb. acidophilus + Bifido. breve + Lb. casei $+\boldsymbol{L}$ b. plantarum; $1: 1: 1: 1)+1 \%$ oat.

A, B, C: Means with same letter among treatments in the same storage period are not significantly different $(p<0.05)$.

$\mathrm{a}, \mathrm{b}, \mathrm{c}$ : Means with same letter for same treatment during storage period are not significantly different $(p<0.05)$.

\section{Conclusion}

It could be concluded that this product meets the requirements for a product to be called a probiotic functional food; final number of viable cells of probiotic strains were within the recommended level at least $10^{6} \mathrm{cfu} / \mathrm{ml}$ or $6 \mathrm{log} \mathrm{cfu} / \mathrm{ml}$. In addition, the sensory, physico-chemical and rheological response to synbiotic-drinkable yoghurts evidenced that the use of probiotic culture specially, Bifidobacterium breve and Lactobacillus plantarum combination with oat positively affected the overall sensory acceptability and improving the nutritional quality.

\section{References}

Abdou, S.M.; Shenana, M.E.; Mansour, N.M. and Zakari, M.K. (2015).Making bioyoghurt using newly isolated lactic acid bacteria with probiotic features.Egypt. J. Dairy Sci. (Supplement, presented in the $12^{\text {th }}$ Egypt. Conf. Dairy Sci. \& Tech., Cairo, 9-11 Nov. pp.
Abou-Dobara, M.I.; Ismail, M.M.; Abdu Mossa, M. and Refat, N.M. (2017). Effect of using vegetarian milk and adding different sweeteners on probiotic activity of Rayeb milk. Amer. J. Microbiol. Biotech., 4(5):44-52.

Akabanda, F.; Owusu-Kwarteng, J.; TanoDebrah, K.; Parkouda, C. and Jespersen, L. (2014). The use of lactic acid bacteria starter culture in the production of Nunu, a spontaneously fermented milk product in Ghana.Int. J. Food Sci., Article ID 721067, 11 pages.

AOAC, (2012). Official methods of Analysis of Association of Official Analytical Chemists $19^{\text {th }}$ ed., Published by AOAC International, Gaithersburg, Maryland, USA.

APHA, (2004). Standards methods for the examination of dairy products. $17^{\text {th }}$ ed., $\mathrm{H}$. Michael Wehr and Joseph F. Frank, editors. American Public Health Association, Washington, DC, USA.

Aryana, K.J.; Plauche, S.; Rao, R.M.; McGrew, P. and Shah, N.P. (2007). Fat-free plain yoghurt manufactured with inulins of various chain 
lengths and Lactobacillus acidophilus. J. Food Sci., 72(3):79-84.

Astawan, M.; Wresdiyati, T.; Suliantari, S.; Arief, I.I. and Septiawan, R. (2012). Production of synbioticyoghurt-like using indigenous lactic acid bacteria as functional food. Media Peternakan, 35(1):9-14.

Bandiera, N.S.; Carneiro, I.; da Silva, A.S.; Honjoya, E.R.; de Santana, E.H.W.; AragonAlegro, L.C. and deSouza, C.H.B. (2013).Viability of probiotic Lactobacillus casei in yoghurt: defining the best processing step to its addition. Arch. Latinoam. Nutr., 63(1):58-63.

Bisar, G.H.; El-Saadany, K.; Khattab, A. and ElKholy, W.M. (2015). Implementing maltodextrin, polydextrose and inulin in making a synbiotic fermented dairy product. British Microbiol. Res. J., 8(5):585-603.

BSI, (1985). Determination of $\mathrm{pH}$ value. BS770 Part 5.

BSI, (1993). Determination of Enterobacteriaceae in microbiological examination of food and animal feeding stuffs. BSI 5763, British Standards Institution, London, U.K.

BSI, (2010). Determination of titratable acidity (Reference method) ISO, 6091, British Standards Institution, London, U.K.

Bujalance, C.; Jiménez-Valera, M.; Moreno, E.; Ruiz-Bravo, A. (2006). A selective differential medium for Lactobacillus plantarum. J. Microbiol. Methods, 66(3):572-575.

Dave, R.I. and Shah, N.P. (1996). Evaluation of media for selective enumeration of Streptococcus thermophilus, Lactobacillus delbrueckiissp. bulgaricus, Lactobacillus acidophilus and bifidobacteria. J. Dairy Sci., 79(9):1529-1536.

Delavari, M.; Pourahmad, R. andSokutifar, R. (2014). Production of low fat synbioticyoghurt containing Lactobacillus Plantarum and inulin. Adv. Environ. Bio., 8(11):17-24.

de Souza, C.H.B.; Buriti, F.C.A.; Behrens, J.H. and Saad, S.M.I. (2008). Sensory evaluation of probiotic Minas fresh cheese with Lactobacillus acidophilus added solely or in co-culture with a thermophilic starter culture. Int. J. Food Sci. \& Tech., 43(5):871-877.

El-Alfy, M.B.; El-Nagar, G.F.; Abd El-Aty, A.M.; Essawy, E.A. and Hammad, M.N.A. (2018). Making of fortified yoghurt with colostrum. Egypt. J. Appl. Sci., 33(3):61-75.

El-Batawy, O.I. and Khalil, O. SF. (2018). Manufacture and properties of low-fat bio yoghurt containing probiotic strains and maltodextrin as prebiotic.J. Prob. Health, 6(1): 192.

El-Kadi, S.M.L.; Ismail, M.M.; Hamad, M.N.F. and Zidan, M.Sh. (2017).Chemical and microbial characterizations of bio-yoghurt made using ABT culture, cow milk and coconut milk.EC Microbiology, 5(3):109-124.
El-Kholy, W.M. and Mahrous, H. (2015). Biological studies on bio-yoghurt fortified with prebiotic obtained from Jerusalem artichoke. Food \&Nutr. Sci., 6(16):1552-1564.

Elliker, P.R.; Anderson, A.W. and Hannesson, G. (1956). An agar medium for lactic acid streptococci and lactobacilli. J. Dairy Sci., 39:1611-1617.

Gamage, G.G.A.P.; Adikari, A.M.J.B.; Nayananjalie, W.A.D.; Prasanna, P.H.P.; Jayawardena, N.W.I.A. and Wathsala, R.H.G.R. (2016). Physicochemical, microbiological and sensory properties of probiotic drinkable yoghurt developed with goat milk. Int. J. Scient. \& Res. Public., 6(6):203-208.

Güler-Akin, M.B.; Ferliarslan, I. and Akin, M.S. (2016). Apricot probiotic drinkable yoghurt supplied with inulin and oat fiber. Adv. Microbiol., 6(14):999-1009.

Gustaw, W.; Kordowska-Wiater, M. andKoziol, J. (2011). The influence of selected prebiotics on the growth of lactic acid bacteria for bio-yoghurt production. Acta Sci. Pol., Tech. Aliment., 10(4):455-466.

Ismail, E. (2007). Characterization and genetic improvement of lactobacilli for application in probiotic dairy products. Ph.D. Thesis, Fac. Agric. \&Nutr. Sci., Christian Albrecht's Univ., Kiel, Germany.

Keogh, M.K. andO'Kennedy, B.T. (1998). Rheology of stirred yoghurts as affected by added milk fat, protein and hydrocolloids. J. Food Sci., 63(1): 108-112.

Kosikowski, F.V. (1984). Cheese and fermented milk foods. $2^{\text {nd }}$ ed., printing Brooktonalds, New York 14817, USA.

Ladjevardi1, Zh. S.; Yarmand, M.S.; EmamDjomeh, Z. and Niasari-Naslaji, A. (2016). Physicochemical properties and viability of probiotic bacteria of functional synbiotic camel yoghurt affected by oat $\beta$ - glucan during storage. J. Agric. Sci. Tech., 18(5):1233-1246.

Lees, G.J. andJago, G.R. (1969). Methods for the estimation of acetaldehyde in cultured dairy products. Aust. J. Dairy Tech., 24(4):181-185.

Lees, G.J. andJago, G.R. (1970). The estimation of diacetyl in the presence of other carbonyl compounds. J. Dairy Res., 37(1):129-132.

Marshall, R.T. (2005). Standard methods for the examination of dairy products. Amer. Public Health Assoc., Washington, D.C.

Narayana, N.M.N.K. and Gupta V.K. (2018).Storage changes and shelf life of strawberry set yoghurt made by milk standardized using ultrafiltered skim milk retentate. Int. J. Sci. \& Tech. Res., 7(8):261-268.

Ong, L. and Shah, N.P. (2009). Probiotic Cheddar cheese: influence of ripening temperatures on survival of probiotic microorganisms, cheese 
composition and organic acid profiles. LWT, Food Sci. \& Tech., 42(7):1260-1268.

Petersen, B.L.; Dave, R.I.; McMahon, D.J.; Oberg, C.J. and Broadbent, J.R. (2000). Influence of capsular and ropy exopolysaccharide-producing Streptococcus thermophilus on mozzarella cheese and cheese whey. J. Dairy Sci., 83(9):1952-1956.

Rodrigues, D.; Rocha-Santos, T.A.B.; Gomes, A.M.; Goodfello, B.J. and Freitas, A.C. (2012). Lipolysis in probiotic and synbiotic cheese: The influence of probiotic bacteria, prebiotic compounds and ripening time on free fatty acid profile. Food Chem., 131(4):1414-1421.

Sarvari, F.; Mortazavian, A.M. and Fazeli, M.R. (2014).Biochemical characteristics and viability of probiotic and yoghurt bacteria in yoghurt during the fermentation and refrigerated storage.Appl. Food Biotech., 1(1):55-61.

SAS, (2008). Statistical Analysis System. SAS User's Guide Statistics/ STAT Ver. 9.2 SAS Inst., Inc., Cary, NC, USA.

Tamime, A.Y. and Robinson, R.K. (1999). Yoghurt: Science and Technology ( $2^{\text {nd }}$ ed.) .Cambridge, UK: Wood head publishing Ltd.

Tammam, A.A.; Abd El-Rahim, A.M. and Mohamed, T.H. (2011). Characteristics of low fat probiotic yoghurt. Assiut J. Agric. Sci.,42(5):1-16.
Tiwari, P.K.; Asgar, S.;Uprit, S.;Chauhan, M.;Choudhary, K.K. andSandey, K.K. (2017). Effect of oat flour addition on the physicochemical properties of synbiotic milk drink.Bull. Env. Pharmacol. Life Sci., 7(1):95-103.

Tiwari, P.K.; Asgar, S.;Uprit, S.;Chauhan, M.;Sandey, K.K. andShinde, N.W. (2019). Effect of oat flour addition on the viability of probiotic micro-organisms during refrigerated storage of synbiotic milk drink.Int. J. Livestock Res., 9(1):66-73.

Van de Casteele, S.; Vanheuverzwijn, T.; Ruyssen, T.; Van Assche, P.; Swings, J. and Huys, G. (2006). Evaluation of culture media for selective enumeration of probiotic strains of lactobacilli and bifidobacteria in combination with yoghurt or cheese starters. Int. Dairy J., 16(12):1470-1476.

Yadav, H.; Jain, S. and Sinha, P.R. (2007).Production of free fatty acids and conjugated linoleic acid in probiotic dahi containing Lactobacillus acidophilus and Lactobacillus casei during fermentation and storage. Int. Dairy J., 17(8):1006-1010.

Yilmaz-Ersan, L. and Kurdal, E. (2014).The production of set-type-bio-yoghurt with commercial probiotic culture.Int. J. Chem. Engineer. \&Applicat., 5(5):402-409. 